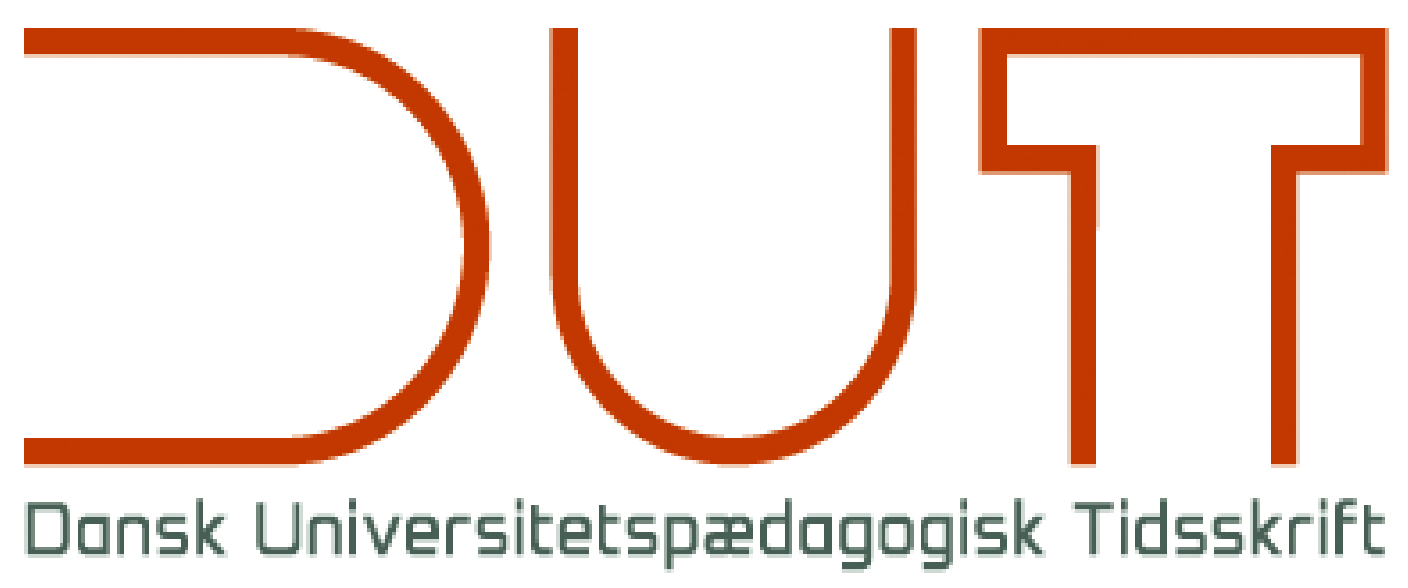

Læringsrum

Årgang 14 nr. 27 / 2019

Titel

Udvikling af studerendes selvstændighed: Stilladsering i bachelorvejledning

Forfattere

Sidetal

Kristina Bakkær Simonsen, Gitte Wichmann-Hansen

$136-154$

Udgivet af

Dansk Universitetspædagogisk Netværk, DUN

URL

> http://dun-net.dk/

Betingelser for brug af denne artikel

(c) Copyright
Denne artikel er omfattet af ophavsretsloven, og der må citeres fra den. Følgende betingelser skal dog være opfyldt:

- Citatet skal være i overensstemmelse med "god skik"

- Der må kun citeres „i det omfang, som betinges af formålet“

- Ophavsmanden til teksten skal krediteres, og kilden skal angives ift. ovenstående bibliografiske oplysninger.

DUT og artiklens forfatter 


\title{
Udvikling af studerendes selvstændighed: Stilladsering i bachelorvejledning.
}

\author{
Kristina Bakkær Simonsen ${ }^{\mathrm{a}, 1}$, Gitte Wichmann-Hansen ${ }^{\mathrm{b}}$ \\ anstitut for Statskundskab, Aarhus Universitet, ${ }^{b}$ Center for Undervisning og Læring, Aarhus Universitet
}

Videnskabelig artikel, fagfællebedømt

I denne artikel undersøger vi hvordan studerendes selvstændighed kan opøves i forbindelse med opgaveskrivning. Vi tager afsæt $\mathrm{i}$ en teoretisk skelnen mellem selvstændighed i processen og i produktet og argumenterer for, at sidstnævnte kan og bør trænes undervejs $i$ et opgaveforløb, så de studerende gradvist opnår øget sikkerhed i videnskabelige formidling. Datagrundlaget er en empirisk case, der indeholder dels en redegørelse for et konkret bacheloropgaveforløb på en samfundsvidenskabelig uddannelse, dels en analyse af forløbets resultater i form af skriftlige evalueringsdata, karakterdata og vejlederens egne observationer. Analysen viser, at vejledere kan fremme progression i studerendes selvstændighed gennem stilladsering, dvs. ved tidligt, gradvist og systematisk at indarbejde forskellige støttende aktiviteter som skriveøvelser, peer-feedback og kollektiv vejledning. Samlet skærper aktiviteterne de studerendes blik på videnskabelige genrekrav og afmonterer dermed meget af den usikkerhed, som de kan have omkring produktkravene til en selvstændig opgave. Resultatet er større mod på opgaveprocessen og højere kvalitet i de endelige produkter.

\section{Introduktion}

Bacheloropgaver og kandidatspecialer er i de fleste studieordninger defineret som en eksamensform, der tester den studerendes evne til at arbejde selvstændigt med et stof. Imidlertid er der en vis uenighed blandt vejledere om, hvordan begrebet selvstændighed skal defineres og fortolkes (Jensen 2016), ligesom mange vejledere er usikre på, om, og i givet fald hvordan, de skal varetage opgaven med at opøve studerendes selvstændighed (Vereijken, van der Rijst, van Driel \& Dekker 2018; Robert \& Seaman 2018). Må de give råd og løsninger, eller skal de lade den studerende selv finde frem til svarene? Hvis de styrer, hjælper og rådgiver for meget, reducerer de måske den studerendes tiltro til egne kompetencer som skriver og forsker (Overall, Deane \& Peterson 2011) og risikerer at gøre studerende (for) afhængige af vejlederens støtte og input. Omvendt kan for lidt hjælp og støtte resultere i usikkerhed og manglende læring og progression (Knudsen 2014; Barnes \& Cheng 2018).

Kravet om selvstændighed i bacheloropgave- og specialeskrivning giver også anledning til tvivl hos mange studerende (Greenbank \& Penketh 2009). Det er veldokumenteret i forskningslitteraturen om bacheloropgaveskrivning, specialeskrivning og -vejledning, at studerende på samfundsvidenskabelige og humanistiske fag især er usikre på, hvor meget hjælp og rådgivning de kan forvente fra vejlederne i startfasen (Todd, Banister \& Clegg 2004; Monyolo, Khaola \& Mokorotlo 2014; Malcolm 2012; Franken 2012). På den ene side forventes studerende i disse afleveringer at udvise en høj grad af selvstændighed i emnevalg og opgavefokus

\footnotetext{
${ }^{1}$ Kontakt: bakkaer@ps.au.dk
} 
(de Kleijn et al. 2016). På den anden side er emnevalg, problemformulering og litteratursøgning det, som studerende oftest finder mest krævende, gerne vil have meget hjælp til og oplever at være mindst rustede til fra deres tidligere opgaveskrivning (Todd et al. 2004; Monyolo et al. 2014). Derfor er mange studerende i tvivl om, hvordan de skal forstå kravet om selvstændighed i startfasen: Forventes de at klare det på egen hånd - eller må de bede om hjælp, råd, idéer og feedback fra vejlederen?

Ovenstående vidner om uklarhed blandt både vejledere og studerende omkring selvstændighedsbegrebet, og hvor meget de studerende skal klare selv. Et gennemgående råd fra vejledningslitteraturen er, at vejledere må tale eksplicit med deres studerende om, hvordan selvstændighed bedømmes i faget og i disciplinen (Rienecker, Wichmann-Hansen \& Stray Jørgensen 2019). Det er også vigtigt, at vejledere indretter graden af styring, hjælp og rådgivning efter de studerendes behov og tidligere erfaringer med opgaveskrivning (Greenbank \& Penketh 2009). Endelig er det et bredt anerkendt råd i litteraturen, at vejledere må give flere instrukser og råd i startfasen og gradvist nedtone det i takt med, at de studerende opnår større erfaring og sikkerhed i arbejdet med projektet og skrivningen (Anderson, Day \& McLaughlin 2006). I et nyligt og stort anlagt studie om specialevejledning og selvstændighed anbefaler Barnes og Cheng (2018), at man igennem hele universitetsstudiet, men også i de enkelte vejledningsforløb, indbygger en progression i de krav, som stilles til de studerende. Med henvisning til 'scaffolding'-begrebet (stilladsering) (Bruner 1978) foreslår de, at vejledere og undervisere hele tiden giver tilpas udfordrende opgaver i forhold til de studerendes aktuelle niveau. Hvis man ikke kan forvente, at de studerende fra starten af et opgaveforløb har et sikkert greb om at lave problemformuleringer eller er fortrolige med videnskabelige genrekrav, må vejlederne sørge for, at de studerende lærer disse ting ved hjælp af forskellige pædagogiske virkemidler fra klar instruktion og demonstration over modeller, metoder og redskaber til mere øvelsesprægede opgaver, dialog og feedback.

Barnes \& Chengs (2018) anbefaling er velunderbygget i interview- og spørgeskemadata, og deres studie bekræfter den øvrige forskning på feltet. Alligevel er der en påfaldende mangel på konkrete bud i litteraturen på, hvordan denne type stilladsering kan gennemføres i praksis, og hvordan vejledere reelt kan designe et forløb, der fremmer progression i de studerendes selvstændighed, således at selvstændighed ikke bliver overladt til de studerende. I dette studie vil vi vise, hvordan undervisere og vejledere kan takle denne opgave didaktisk og metodisk. Vi analyserer resultaterne af et konkret bacheloropgaveforløb, der var tilrettelagt ud fra et ønske om gradvist at opøve de studerendes selvstændighed i opgaveskrivningen, herunder at gøre selvstændighed til et håndterbart, positivt og inspirerende krav for de studerende snarere end et krav forbundet med nervøsitet og usikkerhed. Vi undersøger derfor følgende forskningsspørgsmål:

Hvordan kan studerendes selvstcendighed opøves i undervisnings- og vejledningsforløb, der retter sig mod skrivning af større skriftlige opgaver?

Vi besvarer spørgsmålet ved at analysere en empirisk case, der dels indeholder en detaljeret redegørelse for didaktiske og metodiske overvejelser i forbindelse med planlægning og gennemførelse af et konkret bacheloropgaveforløb på Institut for Statskundskab på Aarhus Universitet, dels en systematisk analyse af forløbets resultater i form af skriftlige evalueringsdata, karakterdata og underviserens/vejlederens egne observationer. Vi vil argumentere for, at undervisere og vejledere bør fokusere på at træne de studerendes evne til at udvise selvstændighed i den videnskabelige formidling, og at peer-feedback og kollektiv vejledning er 
særligt velegnede pædagogiske redskaber til at fremme den enkelte studerendes selvstændighed, på trods af at mange studerende er af den opfattelse, at selvstændighed handler om at arbejde alene. Selvom den aktuelle case drejer sig om bacheloropgaveskrivning, vil vi i artiklens diskussion vise, hvordan (elementer i) designet kan overføres til andre forløb, hvor selvstændighed er i fokus, herunder ikke mindst kandidat-specialeforløb.

Underviseren/vejlederen i den aktuelle case, Kristina Bakkær Simonsen (KBS), er artiklens førsteforfatter. Artiklens andenforfatter, Gitte Wichmann-Hansen (GWH) har vejledning som sit forskningsfelt og har fungeret som pædagogisk sparringspartner i forbindelse med udvikling og afholdelse af bacheloropgaveforløbet.

\section{Selvstændighed, peer-feedback og kollektiv vejledning}

I dette afsnit redegør vi for centrale teorier og begreber, idet vi især forholder os til begrebet selvstændighed og argumenterne bag peer-feedback og kollektiv vejledning som vigtige pædagogiske metoder til at styrke de studerendes selvstændighed.

Som nævnt, er det ikke helt enkelt at fastslå, hvad selvstændighed er i opgaveskrivning. Vi læner os op ad den teoretiske retning, der skelner mellem selvstændighed som produktkrav og selvstændighed som proceskrav (Rienecker, Wichmann-Hansen \& Stray Jørgensen 2019). Selvstændighed i produktet handler om, hvordan den studerende formidler sit arbejde med stoffet, kilderne og metoderne, dvs. i hvilken grad den studerende bruger og forholder sig kritisk til dem i sin opgave. Det er kompetencer, som vejlederen kan observere og identificere i den studerendes tekst(-udkast). Vejlederen kan fx iagttage, om den studerende formidler med en klar forfatterstemme gennem fremsættelse af egne argumenter, transparent præsentation af valg og fravalg og diskussion af styrker og svagheder på en produktiv måde, der hverken underminerer eller oversælger opgaven. Selvstændighed i processen handler derimod om, hvordan den studerende planlægger og udfører sin arbejdsproces, herunder bruger vejlederen og andre ressourcer. Det er kompetencer, som vejlederen kan erfare undervejs i vejledningsprocessen og som til tider - bevidst eller ubevidst - indgår i bedømmelsen af bacheloropgaver og specialer. Vi vil dog fastholde, at selvstændighed som proceskrav ikke bør være en del af bedømmelsesgrundlaget, da det er en kompetence, som censor ikke har adgang til at vurdere. Der findes parametre til at bedømme tekstens selvstændighed, $\mathrm{fx} i$ studieordningernes målbeskrivelser og ministeriets kvalifikationsramme, men i de fleste målbeskrivelser findes der ikke parametre til at bedømme, hvor selvstændig den studerende har været undervejs i processen, fx hvor selvstændigt den studerende har ageret i vejledningssamtalerne og i planlægningen af arbejdet.

Denne skelnen mellem selvstændighed som produktkrav og proceskrav er vigtig, da studerende ofte tror, at selvstændighed betyder, at de skal gøre alt i processen alene (Anderson, Day \& McLaughlin 2008). Det giver usikkerhed, og det risikerer at skabe en oplevelse af, at selvstændig er noget, man enten er eller ikke er, og som de studerende derfor står alene med at håndtere (Greenbank \& Penketh 2009; Barnes \& Cheng 2018). Selvstændighed forstået som en demonstreret kompetence i videnskabelig formidling er derimod noget, som kan trænes og læres og i sidste ende bedømmes². Derfor er vores udgangspunkt, at undervisnings- og vejledningsforløb må designes, så de studerendes selvstændighed gradvist op-

\footnotetext{
${ }^{2}$ Vi bruger her bevidst begrebet kompetence forstået som evnen til at anvende viden og færdigheder i en bestemt situation, hvilket er i overensstemmelse med Undervisningsministeriets brug af kompetencebegrebet.
} 
øves i videnskabelig argumentation og formidling. Det gør selvstændighed til et mere håndterbart og konstruktivt krav, idet det omdannes fra et iboende personlighedstræk til en tilegnelig kompetence.

På baggrund af denne skelnen mellem selvstændighed i processen og produktet vil vi argumentere for, at peer-feedback - og mere generelt de studerendes brug af hinanden som sparringspartnere - er en essentiel del af et didaktisk design, der har til formål at lære studerende at agere selvstændigt i opgaveskrivning. Hvis selvstændighed forstås som en demonstreret kompetence i videnskabelig argumentation og formidling, bliver sparring med andre værdifuldt, hvis ikke nødvendigt, da indsigt i en teksts kvaliteter og udfordringer hviler på dialog med potentielle læsere. Peer-feedback kan defineres som feedback, der gives fra én studerende til en anden i form af kommentarer på hinandens arbejde, adfærd eller præstation, baseret på kriterier, der er defineret på forhånd (Liu \& Carless 2006). Metoden har netop vist sig at være særdeles effektiv til at træne studerende i at forstå og anvende videnskabelighedskriterier og dermed øge studerendes sikkerhed i at skrive akademiske opgaver (Topping 2017). Det gælder både for den, der giver og den, der modtager feedback (Huisman et al. 2018). Desuden er validiteten og reliabiliteten i de studerendes vurderinger af hinandens og andres præstationer generelt høj (Topping 2017). Ud over de faglige gevinster i form af bedre skriftlige præstationer understøtter peer-feedback også udvikling af selvregulerende læringsadfærd hos de studerende samt bedre samarbejds- og kommunikationsevner (Ibid).

En anden pædagogisk metode, som også bygger på idéen om at fostre sparring mellem de studerende, er kollektiv vejledning, der $\mathrm{i}$ al sin enkelhed betyder 'fælles vejledning af studerende, der skriver på forskellige opgaver' (Thomsen \& Nordentoft 2012). I kollektiv vejledning er peer-feedback det centrale omdrejningspunkt suppleret med feedback fra vejlederen, og derfor trækker vejledningsformen på mange af de samme gevinster som peer-feedback. De bærende argumenter bag kollektiv vejledning er, at studerende 1) kommer hurtigere i gang med - og har bedre fremdrift i - skrivningen undervejs, fordi der er fælles milepæle for udkast og møder, 2) socialiseres ind i det faglige diskursfællesskab ved at indgå i en professionel samtale med peers baseret på saglig kritik, og 3) føler sig mindre alene med deres projekter og mindre usikre på skriveprocessen, fordi de får øje på, at de ikke er alene om de problemer, de oplever, og at de både er almindelige og overkommelige (Nordentoft, MariagerAnderson \& Smedegaard 2016).

Fuld udnyttelse af potentialet i peer-feedback og kollektiv vejledning kræver imidlertid

1. En klar rammesætning med retningslinjer for, hvordan feedback skal foregå, herunder tryghed i læringsrummet og fortrolighed med at give og modtage feedback (Hvass \& Heger 2018)

2. Input og styring fra vejlederen i form af løbende korrektion, råd og opsamling på de studerendes diskussioner og feedback (Zhu \& Carless 2018), herunder klare indholdskriterier leveret af underviseren/vejlederen - gerne med inddragelse af de studerende i udvikling af kriterierne (Nicol, Thomson \& Breslin 2014)

3. En forskydning i vejlederens rolle fra 'læremester' til 'facilitator', der animerer til fælles diskussion og refleksion (Wichmann-Hansen, Thomsen \& Nordentoft 2015)

I casebeskrivelsen giver vi eksempler på, hvordan disse hensyn er indarbejdet i det konkrete forløb. 


\section{Analytisk tilgang og datagrundlag}

Vi analyserer casen som en situationsbestemt praksis, der er indlejret i en lokal uddannelseskontekst, som naturligvis sætter nogle rammer for arbejdet med de studerende. Derfor giver vi i næste afsnit en grundig beskrivelse af de specifikke omstændigheder og typen af studerende på det pågældende studium. Det giver læseren indsigt i casens rammebetingelser og danner baggrund for vores diskussion af indsigter af mere generel karakter om, hvordan man kan opøve studerendes selvstændighed i opgaveskrivning. Vi er inspirerede af nyere forskning i uddannelsesudvikling, der argumenterer for, at man må inddrage mange perspektiver og uens materiale for at kunne undersøge og forklare værdien af at lave nye tiltag fremfor at lave simple effektstudier (Bamber og Stefani 2016). Kongsgaard og Rod (2018) formulerer det meget præcist i deres nye bog om forskning og udvikling inden for velfærdprofessioner, hvor de gør op med New Public Management og evidensbølgen:

Målet for denne type effektforskning er ikke at afgøre endegyldigt, hvorvidt en indsats virker eller ej, men at besvare det mere komplekse og sammensatte spørgsmål: Hvad virker, for hvem, hvordan og under hvilke omstoendigheder? (Kongsgaard \& Rod 2018, s. 17).

Vi kombinerer derfor formelle og uformelle data for at give en nuanceret vurdering af de pædagogiske tiltags værdi for opøvelsen af de studerendes selvstændighed. De formelle data, som står i forgrunden af vores analyse, består af:

1. Skriftlige, anonyme evalueringsdata indsamlet online, efter de studerende havde afsluttet forløbet (antal besvarelser: 18, svarprocent: 86). Disse evalueringsdata består for det første af de studerendes svar på 12 lukkede spørgsmål om vurderinger af undervisnings- og vejledningsforløbet (angivet på en skala fra 1-5, hvor 1 angiver "helt uenig" og 5 "helt enig"). Vi sammenligner disse resultater med evalueringsdata fra årgangen af bachelorstuderende (antal besvarelser: 130, svarprocent: 63) og angiver om eventuelle forskelle i evalueringsresultaterne er statistisk signifikante (via. tosidet t-test med $95 \%$ konfidensinterval). Dette skal ikke ses som et forsøg på at behandle casen som en art kontrolleret eksperiment, men snarere som et bidrag til at kontekstualisere analysen, så læseren får indsigt i de parametre, som især adskiller sig ved det nærværende forløb. Vi bemærker i denne forbindelse, at de studerende på det analyserede forløb i flere tilfælde alle har angivet samme score på et givet evalueringsspørgsmål (dvs. standardafvigelsen er 0). I disse tilfælde er det mere informativt at forholde sig til den absolutte værdi (herunder den slående enighed) end at fortolke på signifikanstesten.

2. For det andet de studerendes skriftlige svar på to åbne evalueringsspørgsmål, henholdsvis om hvilke dele af forløbet der "i særlig grad har været en hjælp til at lære stoffet", henholdsvis om de har forslag til forbedringer/har savnet noget. Disse kommentarer kodede vi induktivt med fokus på positive og negative udsagn i relation til undervisningsforløbet (induktive underkoder: interaktion mellem de to spor, fokus på formidling, skriveøvelserne, og læringsmiljø), vejledningsforløbet (induktive underkoder: planlægning, og kollektiv vejledning) og generelle bemarkninger (induktive underkoder: peer-feedback, akademisk selvtillid, og inspiration/motivation). Eftersom kun to udsagn blev kodet som negative (begge ang. timingen af sidste vejledning inden opgaveaflevering jf. koden "planlægning"), fokuserer vi i resultatafsnittet på de gavnlige aspekter af forløbet, hvor vi citerer typiske udsagn fra de kvalitative kommentarer. Vi har ikke adgang til de åbne kommentarer fra resten af årgangen, hvorfor denne del af analysen kun fokuserer på casen. 
3. Karaktergennemsnit for de afleverede opgaver fra studerende på det omtalte forløb (19 i alt) sammenlignet med karaktergennemsnittet for resten af årgangens bacheloropgaver (179 i alt). Også her undersøger vi, om en eventuel forskel er statistisk signifikant.

Vi supplerer ovenstående formelle data med uformelle data bestående af KBS's løbende iagttagelser og refleksioner over de studerendes adfærd i konfrontationstimerne og i vejledningsmøderne, samt en overordnet vurdering af de endelige bacheloropgavers kvalitet, særligt mht. demonstrering af selvstændighed. Det vil sige, at fokus for analysen først og fremmest er de studerendes oplevelser og udbytte, mens underviser-vejleder-observationerne tillader os at supplere de studerendes indtryk, samt give yderligere indblik i om disse afspejledes i deres adfærd og produkter gennem forløbet.

\section{Case}

\section{Kontekst og karakteristik af de studerende}

På uddannelsen i statskundskab tæller bacheloropgaven 20 ECTS og skrives på sjette semester. De studerende følger et seminar i forbindelse med bacheloropgaven, hvis emnefelt de skal skrive opgave inden for. Underviseren er - ud over at være underviser - også bachelorvejleder for de studerende, som følger vedkommendes seminar. Underviser-vejlederen står dermed med en dobbelt opgave: a) at tilbyde undervisning, som bidrager til de studerendes substantielle viden inden for et specialiseret fagområde, og b) at klæde de studerende på til at skrive deres egen bacheloropgave. Undervisningsdelen af semesteret løber typisk over de første 2-2,5 måneder, og herefter tager individuel vejledning over i de sidste 2-2,5 måneder inden aflevering.

Hvert år udbydes omkring 15 bacheloropgaveseminarer. Seminarerne er emnemæssigt spredt over de centrale discipliner på uddannelsen, og de fleste studerende tildeles et seminar blandt deres top-tre prioriteter, hvorfor de typisk er meget motiverede. Dette skal også ses i lyset af, at alle fag på de forudgående fem semestre af uddannelsen er obligatoriske, og bachelorseminaret er dermed forbundet med større valgfrihed, end de studerende er vant til.

Uden ønske om at bidrage til overgeneraliseringer om typen af studerende på forskellige studier (og med det forhold in mente at en årgang af sjettesemesterstuderende på Statskundskab tæller godt 200 studerende og dermed nødvendigvis rummer en del variation), betragtes de studerende på uddannelsen generelt som ambitiøse og seriøse omkring deres studier. Særligt i forbindelse med bacheloropgaven, hvor de som nævnt har medbestemmelse på, hvilket emne de specialiserer sig i, udgør dette grundlaget for en privilegeret undervisningssituation med motiverede studerende, der generelt ønsker at yde en stor indsats for at klare sig godt. Samtidig har de fleste studerende det bedst med at "følge bogen" og den sikre vej, bl.a. fordi undervisningen og eksaminerne på de forudgående semestre lægger meget lidt vægt på kreativitet og selvstændig problemformulering og -løsning. Fx udgør frie hjemmeopgaver - frem for forskellige former for bundne eksamensopgaver - kun to ud af seksten eksaminer inden bacheloropgaven. Som det bemærkes i en inspirationspjece, der bygger på tidligere underviseres erfaringer, og som udleveres til alle bachelorseminarundervisere forud for semesterstart, er bachelorseminaret da også "... det første fag på uddannelsen, hvor de [studerende] skriver en stor selvstændig opgave af denne karakter", og "de studerende bruger rigtig mange kræfter" på at håndtere det nye krav om selvstændighed (Binderkrantz \& Kjær 2015, s. 5). En del studerende er nervøse ved tanken om den tid, der kommer, hvor un- 
dervisningen slutter, og vejledningsdelen går i gang, og de dermed "står alene" med en opgave, de ikke ved, hvordan de skal definere og løse.

I forhold til vejledningsdelen af forløbet har de studerende tidligere på studiet primært mødt instituttets forskere som forelæsere i store auditorier, hvilket betyder, at "de ikke har ret mange tidligere erfaringer med denne type [nære] underviserkontakt, og derfor ikke noget grundlag for at vide, hvad der kan forventes af vejledningen - og af dem selv" (Binderkrantz \& Kjær 2015, s. 7). Det betyder ifølge tidligere undervisere, at nogle studerende bruger vejledningen (for) meget, dvs. kommer med mange detailspørgsmål eller opgaveelementer, som de ønsker, at vejlederen skal tage stilling til. Indtrykket er, at disse studerende har behov for kontinuerligt at blive bekræftet i, at de er på rette vej og at få vejlederens anvisninger på næste skridt i processen. Omvendt er der studerende, som slet ikke kommer til vejledning, hvilket af tidligere undervisere tolkes som et udtryk for, at det for en del studerende er grænseoverskridende at række ud efter vejledning og eksponere tvivl og ufærdige tanker. Selvom disse to typer studerende udviser meget forskellig adfærd, kan begge tolkes som udtryk for manglende akademisk selvtillid, dvs. tro på at kunne foretage egne vurderinger og handle på dem, herunder den medfølgende tryghed ved at præsentere sine idéer for andre.

\section{Poedagogisk udfordring}

Vi kan på baggrund af ovenstående pege på to overordnede pædagogiske udfordringer. For det første udfordringen med at opøve de studerende til selvstændig formidling i deres bacheloropgave, herunder gøre selvstændighed til et håndterbart, positivt og inspirerende krav for de studerende snarere end et umuligt og uoverskueligt krav forbundet med nervøsitet og ængstelighed. For det andet udfordringen med at sikre, at de studerende bruger vejledningen bedst muligt, herunder gøre dem trygge ved at eksponere ufærdige tanker og formulere, hvori deres hjælpebehov består. Optimering af vejledningsdelen var ikke mindst nødvendig set i lyset af, at der var 21 studerende på det pågældende bachelorseminar (og altså kun én vejleder), hvorfor der ikke var uanede vejlederressourcer til rådighed for hver enkelt studerende.

\section{Didaktisk design}

For at imødekomme de pædagogiske udfordringer valgte KBS at stilladsere forløbet, så de studerende gradvist blev trænet $i$ at tænke om sig selv som forskningsformidlere og få praktisk erfaring med selvstændighed som produktkrav. Ét element i stilladseringen var at udnytte strukturen i bachelorseminarmodellen og skabe en større grad af interaktion mellem de to mål med undervisningen: a) at understøtte studerendes tilegnelse af det faglige stof og b) at træne dem i skriftlig videnskabelig formidling. Figur 1 illustrerer designet. 
Figur 1. Undervisningsdesign for bacheloropgaveforløbet

\section{UNDERVISNINGSDESIGN FOR BACHELOROPGAVEFORLØBET}

Del 1: Undervisningsforløb (2mdr)

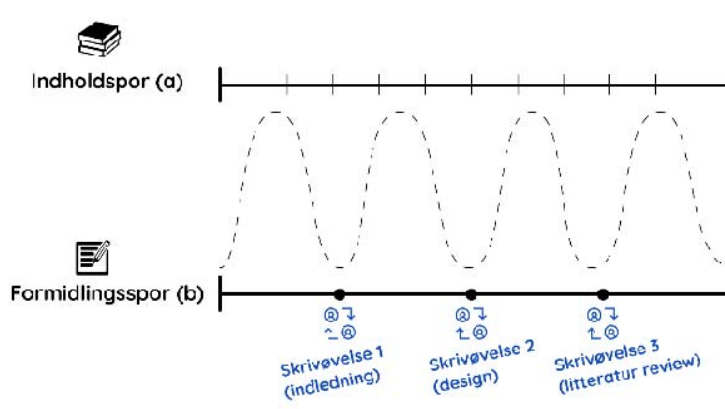

Del 2: Vejledningsforløb (2,5 mdr)

dervisningsdelen, som strakte sig over semestrets første to måneder, inkluderer to parallelle og interagerende spor: indholdssporet (a) og formidlingssporet (b). Interaktionen mellem de to spor blev etableret ved, at de studerende på hver undervisningsgang både skulle forholde sig til fagets teorier og metoder og til videnskabelig formidling heraf. Fx arbejdede de studerende på en undervisningsgang først med at fortolke tre akademiske teksters analyseresultater (indholdssporet), hvorefter de samme teksters indledninger blev analyseret med hensyn til deres struktur og sprog, efterfulgt af en diskussion af, hvad der i de studerendes optik fungerede godt og mindre godt i disse indledninger, og hvad de kunne lade sig inspirere af til deres egne indledninger (formidlingssporet). Interaktionen af de to spor skulle give de studerende et grundlag for at vælge emne til deres opgave med afsæt i viden om litteraturen og samtidig udvikle en tidlig bevidsthed omkring det skrivetekniske arbejde med en akademisk tekst. Dobbeltblikket på pensumteksterne gjorde det desuden muligt at bevæge sig ud over tekstbogsanvisninger på, hvordan man skriver en bacheloropgave og at åbne for et mere kreativt arbejde med videnskabelig formidling, fordi de studerende blev bevidste om og tog stilling til de forskellige måder, hvorpå andre forskere løser formidlingsopgaven.

Formidlingssporet involverede også tre skriveøvelser, som hver havde fokus på en sektion i bacheloropgaven (I) indledning/motivation, II) forskningsdesign og III) litteraturreview). Fx skulle de studerende efter lektionen med analyse af akademiske teksters indledninger selv skrive en indledning til en forestillet forskningsartikel omhandlende det substantielle emne, som lektionen havde fokus på. Den tidligere diskussion af genretræk i pensumteksternes indledninger dannede grundlaget for udformningen af kriterier for gode indledninger, hvorved de studerende inviteredes til at betragte sig selv som forskningsformidlere.

Ud over at opprioritere skriftlig videnskabelig formidling som fokus for undervisningen og sammentænke dette med stoflæringen, blev peer-feedback og kollektiv vejledning introduce- 
ret som værktøjer til at træne de studerendes bevidsthed om, hvad god videnskabelig formidling er, gøre dem tryggere ved kravet om selvstændighed og optimere vejledningsforløbet.

Peer-feedback var en del af arbejdet med de tre skriveøvelser i undervisningsforløbet, og kollektiv vejledning med peer-feedback stod centralt i vejledningsforløbet (se figur 1). Undervisningsforløbets peer-feedbacksessioner stilladserede således det senere vejledningsforløb ved tidligt at træne de studerende $i$ at give og modtage kvalificeret og konstruktiv peer-feedback. Peer-feedback blev faciliteret ved at opdele de studerende i grupper ( $i$ undervisningsforløbet varierede gruppesammensætningerne fra gang til gang), som skulle læse hinandens produkter inden næste undervisnings- eller vejledningsgang. Typisk havde de studerende 2-3 dage til at læse hinandens tekster og forberede feedback. Deling af tekster skete på kursets e-læringsside, mens selve feedbacken altid foregik mundtligt i hhv. klasselokale (i undervisningsforløbet) og mødelokale (vejledningsforløbet). For al produktion af tekst med tilhørende peer-feedback gjaldt følgende elementer:

a) Krav om følgebrev: et kort brev med 1-3 spørgsmål/overvejelser/udfordringer, som den studerende ønskede særlig sparring på. Brevet skulle skærpe den skrivende studerendes bevidsthed om udfordringerne i sin tekst for derved at kunne adskille sig selv fra og kunne redigere i teksten. Derudover skulle følgebrevet forberede forfatteren på at modtage kommentarer ved at tydeliggøre, at der er læsere, som kan inviteres ind som sparringspartnere.

b) Fælles retningslinjer for formen på feedback. Retningslinjerne blev udviklet af de studerende en af de første undervisningsgange og fundet frem forud for hver peerfeedbacksession. At få de studerende til at reflektere over, hvordan feedback bedst leveres, og hvordan de helst selv vil modtage feedback, havde til formål at skabe en forpligtende overenskomst. De fælles retningslinjer blev efterhånden kogt ned til tre ord. Feedback skal være

o konkret ("giv henvisninger/eksempler på, hvad der fungerer godt/mindre godt"),

o begrundet ("hvorfor er X/Y/Z godt/mindre godt?"), og

o konstruktiv ("kom med alternative forslag/argumenter, når du kritiserer").

c) Fælles kriterier for indholdet i feedbacken. Studenterinddragelse i udviklingen af indholdsmæssige kriterier varierede med formaliseringsgraden for og de studerendes tidligere kendskab til den givne genre. I alle tilfælde blev indholdskriterierne talt igennem forud for arbejdet med den relevante tekst for at skabe grundlag for fælles forståelse, og for at de studerende havde mulighed for at udfordre eller tilføje kriterier.

d) Afsluttende refleksion og fælles underviser-/vejlederstyret opsamling. Som afslutning på hver peer-feedbacksession reflekterede de studerende over, hvad de ville tage med til det videre arbejde med deres tekst, og samlede i fællesskab op på gode råd udledt af diskussionerne i feedbackgrupperne. Intentionen med at sætte tid af til opsamling var at tydeliggøre, at feedback ikke er endestationen, men snarere starten på det videre arbejde. Samtidig var målet at forstærke oplevelsen af, at feedback ikke blot er en pædagogisk øvelse i at være gode studiekammerater, men et konstruktivt redskab til sparring og udvikling af ens bevidsthed omkring tekstlige videnskabelighedskriterier. 
Som nævnt er bacheloropgaveseminarets vejledningsforløb på Statskundskab traditionelt baseret på individuel vejledning, men KBS valgte at skubbe vægten over mod en større grad af kollektiv vejledning med peer-feedback. Formålet var at videreføre og forstærke de positive effekter af peer-feedback, som undervisningsforløbet allerede havde vist (mere herom i resultatafsnittet), herunder at gøre de studerende til hinandens sparringspartnere og allierede for at løsne op for oplevelsen af at stå alene med bacheloropgaven. Samtidig var det en ambition, at det fortløbende arbejde med at forholde sig konstruktivt og kritisk til andre studerendes produkter skulle få en afsmitningseffekt på, hvordan de studerende forholdt sig til egne produkter. Peer-feedbacken var således også tænkt som en øvelse i at give sig selv feedback. Endelig gav de fælles møder KBS mulighed for at fremhæve generelle pointer og råd på basis af de studerendes og hendes egen feedback.

Til brug for kollektiv vejledning blev de studerende ved undervisningsforløbets ophør sat sammen i metodegrupper (tre til fem studerende) på baggrund af sammenfald i dataindsamlings- og/eller -analysemetode, som anbefalet af Nexø (2015, s. 21). Hver metodegruppe blev indkaldt til kollektiv vejledning to gange efter en indledende synopsisvejledning (med mulighed for en til to individuelle vejledningsmøder herimellem, se figur 1). Det første møde efter synopsisvejledningen fokuserede på dataindsamling, mens det sidste møde fokuserede på udkast til dele af bacheloropgaven. Disse kollektive vejledningsmøder med vejleder-bestemt indhold skulle sætte nogle pejlemærker for de studerendes arbejds- og skriveproces.

\section{Resultater}

Inden vi mere specifikt analyserer værdien af de didaktiske tiltag, vil vi som generel observation fra de skriftlige evalueringer fremhæve, at de studerende er yderst tilfredse med forløbet, idet gennemsnitsvurderingen af det overordnede udbytte er på 4,9 (på en skala fra 1-5). Som kontekst vil vi samtidig bemærke, at der generelt er stor tilfredshed $(4,6)$ med bachelorseminarerne på årgangen, men at det konkrete forløb på alle evalueringsspørgsmål bliver vurderet (endnu) mere positivt. I belysningen af tiltagenes værdi for opøvelsen af selvstændighed fokuserer vi i det følgende på a) opprioriteringen af formidlingsopgaven i undervisningsforløbet, b) værdien af peer-feedback og kollektiv vejledning, og c) kvaliteten af de endelige bacheloropgaver. Tabel 2 giver et overblik over de kvantitative evalueringsresultater for de studerende på det analyserede forløb, sammenlignet med årgangsresultaterne.

Tabel 1. Kvantitative evalueringsresultater: Casen sammenlignet med resten af årgangen

\begin{tabular}{|l|c|c|}
\hline Evalueringsspørgsmål & Case & Resten af årgangen \\
\hline $\begin{array}{l}\text { *Jeg vurderer det samlede udbytte af kurset som... } \\
\text { meget stort (5) - intet (1) }\end{array}$ & $\begin{array}{c}4,9 \\
(0,24)\end{array}$ & $\begin{array}{c}4,6 \\
(0,59)\end{array}$ \\
\hline $\begin{array}{l}\text { *Underviseren gjorde det klart, hvad han/hun } \\
\text { forventede af os i dette kursus }\end{array}$ & $\begin{array}{c}4,5 \\
(0)\end{array}$ & $\begin{array}{c}4,5 \\
\text { *Gennem kurset var der løbende mulighed for at } \\
\text { afprøve min forståelse af det, jeg har lært, og i den } \\
\text { forbindelse få opklaret fejl og misforståelser }\end{array}$ \\
\hline $\begin{array}{l}\text { *Der har i undervisningsforløbet været gode } \\
\text { muligheder for at få tilbagemelding/vejledning } \\
\text { vedrørende mine faglige præstationer }\end{array}$ & $\begin{array}{c}5 \\
(0)\end{array}$ & $\begin{array}{c}4,4 \\
(0,76)\end{array}$ \\
\hline
\end{tabular}




\begin{tabular}{|c|c|c|}
\hline $\begin{array}{l}\text { *Kursets struktur understøttede min tilegnelse af } \\
\text { fagets indhold }\end{array}$ & $\begin{array}{c}5 \\
(0)\end{array}$ & $\begin{array}{c}4,5 \\
(0,65)\end{array}$ \\
\hline $\begin{array}{l}\text { Kursussiden understøttede kursets undervisnings- } \\
\text { og læringsaktiviteter }\end{array}$ & $\begin{array}{c}4,6 \\
(0,78)\end{array}$ & $\begin{array}{c}4,2 \\
(1,13)\end{array}$ \\
\hline $\begin{array}{l}\text { Jeg har kunnet få faglig hjælp og støtte fra mine } \\
\text { medstuderende i dette kursus }\end{array}$ & $\begin{array}{c}4,6 \\
(0,61)\end{array}$ & $\begin{array}{c}4,5 \\
(0,73)\end{array}$ \\
\hline $\begin{array}{l}\text { *Jeg har involveret mig aktivt i kursets } \\
\text { undervisnings- og læringsaktiviteter både i og } \\
\text { mellem timerne }\end{array}$ & $\begin{array}{c}5 \\
(0)\end{array}$ & $\begin{array}{c}4,5 \\
(0,60)\end{array}$ \\
\hline $\begin{array}{l}\text { *Jeg er gennem undervisningen blevet inspireret til } \\
\text { at arbejde med faget }\end{array}$ & $\begin{array}{c}5 \\
(0)\end{array}$ & $\begin{array}{c}4,6 \\
(0,61)\end{array}$ \\
\hline $\begin{array}{l}\text { I gennemsnit har jeg brugt følgende antal timer pr. } \\
\text { uge på dette }\end{array}$ & $\begin{array}{c}15,9 \\
(6,03)\end{array}$ & $\begin{array}{r}16,2 \\
(5,47)\end{array}$ \\
\hline *Underviseren var god til at formidle stoffet & $\begin{array}{c}5 \\
(0)\end{array}$ & $\begin{array}{c}4,7 \\
(0,53)\end{array}$ \\
\hline $\begin{array}{l}\text { *Underviseren var god til at forstå, hvor vi kunne } \\
\text { have vanskeligheder med stoffet }\end{array}$ & $\begin{array}{c}4,9 \\
(0,32)\end{array}$ & $\begin{array}{c}4,5 \\
(0,66)\end{array}$ \\
\hline $\mathrm{N}$ & 18 & 130 \\
\hline
\end{tabular}

Note: Hvis ikke andet er angivet, er spørgsmålene besvaret på en 1-5-skala, hvor 5 angiver "Enig" og 1 angiver "Uenig". Kolonnerne rapporterer middelvcerdier med standardafvigelse i parentes. * angiver statistisk signifikant forskel i evalueringsresultaterne for casen og resten af årgangen på baggrund af tosidet t-test med $95 \%$ konfidensinterval (forskellig varians).

\section{Undervisningsforløbets fokus på selvstcendig formidling}

Et gennemgående træk i de åbne evalueringssvar er en stor begejstring for tidligt og løbende at træne det skriftlige aspekt af bacheloropgaven. Fire studerende fremhæver specifikt formidlingssporet, og at de gennem undervisningsforløbet er blevet bevidste om, "hvordan man skriver en opgave," fordi "alle timer havde fokus på en bestemt del af opgaveskrivning, hvilket var meget givende." De studerende understreger, at det især var godt, at dette formidlingsfokus løb "hele vejen igennem", dvs. at de på hver undervisningsgang ikke blot forholdt sig til fagets teorier og metoder, men også til at "kunne skrive en god opgave i slutningen af forløbet." Dette peger på, at opprioriteringen af formidlingssporet og stilladseringen af forløbet (Barnes \& Cheng 2018) har haft den intenderede effekt, at forberede de studerende til det mere selvdrevne forløb senere. Dette understreges af, at næsten alle, som har udfyldt evalueringen, erklærer sig helt enige i, at de har fået god vejledning i forhold til at "strukturere min opgave" og "styre og planlægge mit projekt" (gennemsnitsvurderinger på hhv. 4,9 og 5; bemærk at disse supplerende evalueringsspørgsmål ikke blev stillet til resten af årgangen). I denne forbindelse fremhæves skriveøvelserne i de åbne svar som "en virkelig stor hjælp til, at man tidligt kunne komme i gang med at øve [sig på bacheloropgaven]", og en studerende beskriver endda skriveøvelserne som en "praktisk erfaring til opgaven", hvilket illustrerer idéen om at lade de studerende få skrivekompetencerne ind under huden, før de står med den store opgave. 
Det skal understreges, at de studerende ikke nødvendigvis syntes, det var let at arbejde med formidling. Tidligt i forløbet gav flere overfor KBS udtryk for, at det kunne være lidt hårdt, at de fra starten af semestret skulle forholde sig til dets slutprodukt: bacheloropgaven, og at deres medstuderende på andre bachelorseminarer ikke behøvede dette, men kunne fokusere på stoflæring. Samtidig konkluderede de, at det var "godt, at vi hele tiden har været tvunget til at tænke selvstændigt over vores opgaver (altså krav om følgebrev fx)", som en studerende formulerer det i den skriftlige evaluering. Selvom de altså blev konfronteret med egen nervøsitet over at skulle skrive en bacheloropgave i anden halvdel af semestret, var den "tvungne" øvelse heri med til at give de studerende en følelse af at være bedre klædt på end deres medstuderende, hvilket i sidste ende afhjalp en del af den oprindelige nervøsitet. Det tidlige og løbende fokus på formidling havde således som resultat, at de studerende blev tryggere ved og oplevede større kompetence til det senere selvdrevne arbejde.

\section{Peer-feedback og kollektiv vejledning}

Ambitionen om at gøre de studerende til hinandens sparringspartnere og allierede (Nordentoft et al. 2016) bar i høj grad frugt og illustreres blandt andet ved, at seks studerende i evalueringernes åbne svar fremhæver, at der - som én af disse specifikt udtrykker det - har været "et virkelig godt læringsmiljø på holdet, hvor vi støtter hinanden." Denne meget positive fremhævelse af læringsmiljøet og samarbejdet med de andre studerende er især værd at notere i betragtning af, at de studerende ikke alle kendte hinanden i forvejen og ikke havde gået på hold sammen før, idet prioriteringssystemet i tildelingen af bachelorseminarer nødvendigvis fører til et opbrud $i$ de gamle hold. Vi ser den løbende og integrerede peerfeedback i første del af forløbet som et vigtigt element i etableringen af dette positive og støttende læringsmiljø. Efter undervisningsforløbets afslutning (hvor nogle studerende ellers kan miste kontakten til de andre) blev mange af de gode peer-dynamikker fastholdt med forankring i de kollektive vejledningsgrupper. Det var for KBS tydeligt, at de studerende investerede i hinandens projekter i disse grupper, og at de også gjorde brug af hinanden mellem vejledningsmøderne til vidne om, at funktionen som peers var blevet naturlig og ikke længere krævede iscenesættelse fra en underviser-vejlederautoritet (Wichmann-Hansen, Thomsen \& Nordentoft 2015). KBS observerede, at peer-feedbacken - ud over at have positive sociale effekter - også havde høj indholdsmæssig kvalitet, som forbedredes for hver gang og levede op til formkravene om begrundet, konkret og konstruktiv feedback (Hattie \& Timperley 2007). Samtidig viste de studerende mod til at gå kritisk til hinandens tekster med en tydelig motivation om at ville hjælpe hinanden med at forbedre produktet. Det stærke sociale miljø betød således ikke en tilbageholdenhed med at udfordre hinanden og komme med kritik, men snarere at de studerende som peers engagerede sig kreativt og konstruktivt i hinandens arbejde. En kommentar fra de skriftlige evalueringer understreger KBS's observationer: "vi har øvet os i god og fokuseret feedback. Det betyder, at læsninger af andres opgaver og feedback har givet et kæmpe udbytte (i stedet for at man som på nogle andre fag alle famler i blinde og vejleder hinanden i blinde)."

Endelig havde peer-feedbacken positive afledte effekter på de studerendes interaktioner med KBS som vejleder. Vi vil især fremhæve brugen af følgebrev (Rienecker, WichmannHansen \& Stray Jørgensen 2019), som de studerende havde trænet at formulere i forbindelse med skriveøvelserne i undervisningsforløbet, og som også var krav til alle kollektive og individuelle vejledninger. Disse følgebreve var generelt analytisk skarpe omkring den pågældende teksts udfordringer, hvilket betød, at de studerende kom velforberedte og fokuserede til vejledning. Fordi de studerende havde lært konkret at formulere deres hjælpebehov (ikke 
mindst et resultat af at de havde øvet sig i at give konkret feedback til andre), blev vejledningstiden udnyttet bedst muligt, nemlig på at søge løsninger på udfordringerne, snarere end - som det ellers ofte kan ske - at bruge meget af tiden på at afklare selve hjælpebehovet (jf. Binderkrantz \& Kjær 2015). Afledt heraf gav de studerende udtryk for stor tilfredshed med vejledningen, fordi de oplevede at "få svar" på det, de kom med, hvilket bl.a. kommer til udtryk ved, at alle, der har udfyldt evalueringen, erklærer sig helt enige $i$, at der "gennem kurset løbende var mulighed for at anvende det, jeg har lært, og i den forbindelse få opklaret fejl og misforståelser" (gennemsnitsvurdering 5, sammenlignet med 4,5 for resten af årgangen), og at "der i undervisningsforløbet har været gode muligheder for at få vejledning vedrørende mine faglige præstationer" (gennemsnitsvurdering 5, sammenlignet med 4,4 for resten af årgangen).

\section{Bacheloropgavernes kvalitet}

Opøvelsen til selvstændighed bar igennem til bacheloropgaverne, som var af høj kvalitet. Ét udtryk herfor er et meget flot karaktersnit på 9,9 sammenlignet med et snit på 8,5 for resten af årgangen. Selvom karaktersnittet altså også er højt for resten af årgangen, er det alligevel bemærkelsesværdigt, at de studerendes opgaver på det pågældende forløb i gennemsnit vurderes næsten 1,5 point bedre. Denne forskel er statistisk signifikant $(p<0,05)$. Den eksterne censor fremhævede, at opgaverne var solide og velgennemførte, herunder at de studerende evnede at fremlægge valg og fravalg relateret til opgavens styrker og udfordringer på en transparent og nuanceret måde, uden at pille egen opgave ned. Opgaverne var skrevet med sikre forfatterstemmer og bar præg af en iver for at overbevise læseren om vigtigheden af den givne undersøgelse.

Som positiv afledt effekt af øvelsen af selvstændighed som formidlingskompetence udviklede mange studerende gennem forløbet større akademisk selvtillid, hvilket i bacheloropgaverne kom til udtryk gennem modige og kreative valg, fx ved at undersøge en kompleks problemstilling eller vælge en dataindsamlings- eller analysemetode, som de ikke havde megen tidligere erfaring med. Dette understreges af, at samtlige studerende, der har udfyldt evalueringen, erklærer sig helt enige i, at de "gennem undervisningen er blevet inspireret til at arbejde med faget" (gennemsnitsvurdering 5, sammenlignet med 4,6 for resten af årgangen). En del studerende gav også udtryk for, at de tidligere ville være gået en mere sikker vej, men følte sig stærke nok til at tage et spring, der i højere grad var båret af deres akademiske interesse end af strategiske overvejelser som fx at få en høj karakter. Som én studerende skriver i evalueringen:

På Kristinas kursus har jeg for første gang i min studietid følt mig oprigtigt inspireret, stolt af min egen indsats og motiveret. Tidligere har de fleste fag for mig handlet mere om karakterer og et ønske om at få overstået faget, også selvom det har varet spcendende. Kristina har formået at vaere så inspirerende, at jeg tør stole på mig selv og stole på, at jeg er dygtig nok og god nok til selv at skrive en bacheloropgave. Hun har givet mig mod på at vaelge et emne udelukkende ud fra, hvad jeg synes var mest spoendende, og uden tanke på hvad der ville vore nemmest eller hurtigst gennemførbart.

Selvom disse valg virkede mindre "sikre" (og samtidig mere spændende og kreative) for de studerende, har de altså hverken haft negative konsekvenser for bedømmelsen eller for deres egen oplevelse af opgaveprocessen - snarere tværtimod. 


\section{Diskussion}

Vi har i denne artikel analyseret en konkret case, som repræsenterer to meget typiske og relaterede udfordringer i forbindelse med skrivning af større opgaver på universitetet: Hvordan opøves de studerendes kompetencer i selvstændig formidling, og hvordan understøtter man, at de i arbejdet med den selvstændige opgave bruger vejledningen bedst muligt? Med afsæt i litteraturens råd om stilladsering og progression i selvstændighed (Barnes \& Cheng 2018) har vi illustreret, hvordan disse udfordringer kan angribes, ved at de studerende tidligt i forløbet forholder sig til videnskabelige genrekrav som en vigtig del af arbejdet med deres opgave, samtidig med at denne opgave brydes op i mindre dele, som de kan øve sig på og sparre med hinanden omkring i strukturerede rammer, før de befinder sig i det mere selvdrevne opgaveskrivnings- og vejledningsforløb.

Casen er et eksempel på, hvordan et forløb, der umiddelbart virker uoverskueligt og ligefrem lidt skræmmende for de studerende, kan tilrettelægges på en måde, som gør selvstændighed til et inspirerende og motiverende krav. I forhold til de to pædagogiske udfordringer viser både de formelle og uformelle data, at det i den konkrete case lykkedes at optimere vejledningen, fordi de studerende - i kraft af løbende og gentagen øvelse i at give og modtage feedback - blev trænede i at være analytiske omkring egne og andres tekster og dermed blev i stand til at formulere deres hjælpebehov og gå konstruktivt i dialog omkring mulige løsninger. Afledt heraf, resulterede forløbet i opgaver af meget høj kvalitet, hvilket understreger, at de studerende, både i deres egen oplevelse af skrivningen og i eksamensøjemed, lærte at demonstrere selvstændighed.

I vurderingen af analysen vil vi fremhæve, at vores undersøgelse er baseret på fyldige data om konteksten og de didaktiske valg i det konkrete undervisningsforløb samt værdien af det set både fra de studerendes og fra underviseren/vejlederens (og censors) perspektiv. Derudover sammenholder vi disse resultater med evaluerings- og karakterdata for resten af årgangen. Da vi ikke har detaljeret kendskab til, hvordan de øvrige bachelorforløb på årgangen er organiseret, og hvilke undervisnings- og vejledningsformater, de gør brug af, kan sammenligningen imidlertid ikke bruges til endegyldigt at afgøre, hvilke elementer i det konkrete forløb der gør en forskel i forhold til de øvrige forløb. Vi har heller ikke haft mulighed for at vurdere casen i forhold til tidligere undervisningsforløb, da det er første gang, dette forløb har kørt. Sådanne effektmålinger er dog heller ikke formålet med vores analyse. Vores ærinde, når vi sammenligner med resten af årgangen, er at vise, at casen udmærker sig på væsentlige kvalitetsparametre som karakterer og evaluering, hvilket er et argument for at analysere den i detaljen og på dens egne præmisser, dvs. at beskrive og analysere den som et konkret eksempel på, hvordan man didaktisk kan designe et forløb, der stilladserer og fremmer progression i de studerendes selvstændighed. Sammenligningen med årgangens resultater viser netop, at de strukturerede bachelorseminarer på uddannelsen generelt evalueres meget positivt af de studerende, mens de tiltag, der er gjort på det konkrete forløb mht. iscenesættelse af peer-feedback, brug af skriveøvelser og kollektiv vejledning, yderligere synes at have bidraget til de studerendes læring i forhold til selvstændig formidling.

I det følgende vil vi diskutere, hvilke dele af forløbet der med fordel kan overføres til andre sammenhænge. Vi vender således tilbage til Kongsgaard og Rods $(2018$, s. 17) diktum om at undersøge, "hvad virker, for hvem, hvordan og under hvilke omstændigheder?" Det er klart, at den analyserede case repræsenterer nogle gunstige betingelser i form af motiverede og generelt engagerede studerende. Vi mener dog ikke, at dette tager noget fra det didaktiske 
og metodiske design - snarere kunne man argumentere, at der i endnu højere grad kan være grund til at stilladsere forløb for studerende i kontekster, der tilbyder mindre gunstige forudsætninger.

Mht. hvad der virker og hvordan, vil vi fremhæve fire elementer: skriveøvelserne, kravet om følgebrev, den gradvise øvelse i at give og modtage feedback og kollektiv vejledning. Skriveøvelser fungerer som et nyttigt redskab til stilladsering ved at give de studerende en chance (eller rettere: flere chancer) for at skrive tekster, som føles mindre "afgørende", og som de derfor kan lære af, inden de skal gøre noget lignende i deres egen opgave. Hvis andre undervisere vil afprøve samme koncept, vil vi foreslå, at skriveøvelserne netop præsenteres som øvetekster, hvis emnefelt ikke behøver være snævert knyttet til bacheloropgave- eller specialeemnet. Således bliver det lettere for de studerende at fokusere på de formidlingsmæssige aspekter af at skrive en tekst i den givne genre, og det giver dem et frirum til at øve sig, være kreative - og begå fejl. Dette råd bakkes op af den forskning, der anskuer skrivning som en akademisk identitetsproces, og som finder, at studerende har brug for trygge læringsrum for at blive fortrolige med at skrive i en videnskabelig genre (Aitchison \& Guerin 2014).

Kravet om følgebrev og øvelsen i peer-feedback har mange ens effekter og understøtter samtidig hinanden. Kravet om, at enhver tekst, som skal kommenteres, ledsages af et følgebrev med angivelse af spørgsmål eller udfordringer, gør de studerende mere analytiske omkring deres egen tekst. Øvelsen i at give feedback gør de studerende mere analytiske omkring andres tekster - hvilket igen har afsmitningseffekter på, hvordan de griber deres egen skrivning an (Nicol et al. 2014). Denne analytiske bevidsthed har i vores case vist sig nyttig i form af at optimere vejledningen og styrke den selvstændige formidling. Ikke mindst betød det, at de studerende tidligt i skrivningen havde læseren i tankerne, hvilket flere skriveforskere argumenterer for er en styrke, fordi det øger modtagerbevidstheden i den videnskabelig kommunikation (Booth et al. 2016; Sword 2012).

Den kollektive vejledning virker også ved at skabe større analytisk bevidsthed om egen og andres tekster, og i tillæg hertil giver denne vejledningsform struktur og motivation til de studerendes selvdrevne arbejde, fordi vejledningsmøderne sætter nogle fælles milepæle, der opleves som forpligtende. Endelig giver den kollektive vejledningsform de studerende et fagligt-socialt sikkerhedsnet af sparringspartnere, som kan aktiveres mellem møderne med vejlederen. Vores resultater underbygger dermed erfaringer, som andre danske vejledere har dokumenteret i studier af kollektiv vejledning, nemlig at formen både fremmer fremdrift og fællesskab (Niclasen 2016; Nordentoft, Wichmann-Hansen \& Thomsen 2013).

På baggrund af erfaringerne fra den analyserede case vil vi særligt fremhæve de positive effekter, vi fandt ved at kombinere kollektiv vejledning med tidlig øvelse i peer-feedback. Den gradvise træning i peer-feedback i forbindelse med mindre skriveøvelser forbereder tydeligvis de studerende til at indgå i det senere og mere forpligtende fællesskab i de kollektive vejledningsmøder, ligesom peer-feedbacken tidligt giver de studerende forståelse for de positive effekter af at investere i hinandens projekter. Studerende har ofte modvilje mod at indgå i peer-feedback processer, fordi de helst blot vil have underviserens ("ekspertens") respons. Derfor er det særligt væsentligt at markere, når studerende reelt ser en værdi i at investere i peer-feedback. Et studie af Cho \& Schunn fra 2007 dokumenterer overbevisende, at studerendes skrivefærdigheder forbedres signifikant fra første til sidste udkast, når de får peerfeedback i grupper sammenlignet med peer-feedback fra en enkelt studerende eller kun fra deres underviser. Særlig interessant viser studiet, at der er mindst effekt og læring, når de 
kun får feedback fra underviseren. I lighed med Cho \& Schunn (2007) finder vi, at studerendes skrivefærdigheder kan opøves effektivt, hvis de stilladseres gennem øvelser, der gradvist opbygger genrekendskab og kombineres med peer-feedback.

For hvem og under hvilke omstoendigheder vil disse didaktiske tiltag virke? Det er klart, at det analyserede forløb egner sig godt til at øve peer-feedback og anvende kollektiv vejledning, fordi bacheloropgaveseminaret samler mange studerende og giver mulighed for give fælles introduktion til de pædagogiske tiltag før vejledningsforløbet for alvor begynder. Der er dog intet til hinder for at anvende de fire elementer, vi har diskuteret ovenfor, på forløb med færre studerende, og på forløb som ikke følger en seminarstruktur (men kun baserer sig på vejledning). Dog er det åbenlyst, at der som minimum må være to (og gerne tre eller fire) studerende, der har nogenlunde samme proces (fx samme start- og slutdato) og gerne et vist overlap i fx emnefelt, design eller metode. Det sidste behøver dog ikke være nogen forudsætning, såfremt fokus er på den selvstændige formidling (snarere end det konkrete indhold) i peerfeedback og kollektive vejledningssessioner.

\section{Konklusion}

Vi konkluderer ved at fremhæve fem generelle indsigter fra analysen, som besvarer vores forskningsspørgsmål: Hvordan kan studerendes selvstœendighed opøves? For det første vil vi understrege vigtigheden af, at undervisere og vejledere anerkender, at selvstændighed ikke er noget, de studerende selv må finde ud af at udvikle. Selvstændig formidling i videnskabelige tekster er en kompetence, som kan og skal læres, lige såvel som de studerende skal lære om teori og metode. Derfor bør selvstændighed sættes i scene og præsenteres af undervisere/vejledere som noget, studerende kan demonstrere i deres produkt, og der bør være mulighed for, at de studerende kan øve denne kompetence og få feedback i strukturerede rammer.

For det andet - og i forlængelse af den første konklusion - er det vigtigt, at selvstændighed ikke forstås af hverken undervisere/vejledere eller studerende i betydningen "at gøre alting selv". Dette relaterer sig ikke blot til vores skelnen mellem selvstændighed i produktet og selvstændighed i processen, men desuden til den centrale pointe, at de studerendes arbejde med selvstændig formidling styrkes gennem samarbejde med andre studerende (herunder gennem peer-feedback og kollektiv vejledning). Mao. bør det understreges for de studerende, at de ikke klarer sig bedst ved kun at investere i deres eget projekt, men derimod (selv) kan få meget ud af at investere i medstuderende.

For det tredje er det væsentligt at fremhæve, at peer-feedback og kollektiv vejledning både styrker de studerendes refleksion over god formidling og bevirker, at de føler sig mindre alene med deres opgave - selvom den er et selvstændigt projekt. Dette sociale aspekt af peerfeedback og kollektiv vejledning skal ikke underkendes, da det giver de studerende større overskud og større mod på opgaveprocessen.

For det fjerde vil vi minde om, at undervisere og vejledere ikke kan regne med, at peerfeedback "virker af sig selv", dvs. uden at det iscenesættes og øves i et underviser/vejledersuperviseret miljø først. Som det fremgår af en af de skriftlige evalueringer fra den analyserede case, oplever de studerende, at de på andre fag til tider "famler i blinde og vejleder hinanden i blinde," når de skal give peer-feedback, mens øvelse og strukturering sikrer "et kæmpe udbytte". Peer-feedback er med andre ord ikke en erstatning for underviser- 
/vejlederengagement, men engagementet ligger et nyt sted, nemlig på at facilitere de studerendes proces og samarbejde snarere end at agere læremester $\mathrm{i}$ traditionel forstand.

Som det femte og sidste vil vi fremhæve, at en potentiel afledt effekt af øvelsen i selvstændighed er større akademisk selvtillid, dvs. oplevelsen af at kunne træffe og løfte mere interessedrevne og "modige" valg. Således kan et resultat af arbejdet med selvstændig formidling blive en mere generel styrkelse af de studerende og deres selvbevidsthed.

\section{Tak}

Tak til Mathias Elmose Andersen, Center for Uddannelse og Læring - Aarhus Universitet (CUL), for grafisk hjælp med artiklens figur. Vi ønsker også at takke Mustapha Ali El-Ahmad, Mette Tikær Brock, Salma Mohamed og Maja Hjerrild, CUL, for assistance i forbindelse med adgang til og -behandling af evalueringsdata.

\section{Referencer}

Aitchison, C. \& Guerin, C. (red.) (2014). Writing Groups for Doctoral Education and Beyond: Innovations in practice and theory. New York: Routledge.

Anderson, C., Day, K. \& McLaughlin, P. (2006). Mastering the Dissertation: Lecturers' Representations of the Purposes and Processes of Master's Level Dissertation Supervision. I: Studies in Higher Education, 31 (2), 149-168.

Anderson, C., Day, K. \& McLaughlin, P. (2008). Student Perspectives on the Dissertation Process in a Masters Degree Concerned with Professional Practice. I: Studies in Continuing Education, 30 (1), 33-49.

Bamber, V. \& Stefani, L. (2016). Taking up the Challenge of Evidencing Value in Educational Development: From Theory to Practice. I: International Journal for Academic Development, 21 (3), 242-254.

Barnes, G.P. \& Cheng, M. (2018). Working Independently on the Dissertation Proposal: Experiences of International Master's Students. I: Journal of Further and Higher Education. Online 11. april 2018.

Binderkrantz, A. \& Kjær, A.M. (2015). Bachelorseminarer: Inspiration til planloegning og gennemførsel. Aarhus: Institut for Statskundskab, Aarhus Universitet. 2. udgave.

Booth, W.C., Colomb, G.G., Williams, J.M., Bizup, J., Fitzgerald, W.T. (2016). The Craft of Research. (Fourth Edition). Chigaco: University of Chicago Press.

Bruner, J. S. (1978). The role of dialogue in language acquisition. In A. Sinclair, R. J. Jarvelle, and W. J.M. Levelt (eds.) The Child's Concept of Language. New York: Springer-Verlag.

Cho, K., \& Schunn, C. D. (2007). Scaffolded writing and rewriting in the discipline: A web-based reciprocal peer review system. Computers \& Education, 48(3), 409-426.

de Kleijn, R.A.M., Bronkhorst, L.H., Meijer, P.C., Pilot, A., \& Brekelmans, M. (2016). Understanding the Up, Back, and Forward-Component in Master's Thesis Supervision with Adaptivity. I: Studies in Higher Education, 41 (8), 1463-1479. 
Franken, M. (2012). Re-Situation Challenges for International Students "Becoming" Researchers. I: Higher Education, 64 (6), 845-859.

Greenbank, P., \& Penketh, C. (2009). Student Autonomy and Reflections on Researching and Writing the Undergraduate Dissertation. I: Journal of Further and Higher Education, 33 (4), 463-472.

Hattie, J., \& Timperley, H. (2007) The Power of Feedback. I: Review of Educational Research, 77 (1), 81-112.

Huisman, B., Saab, N., Driel, J. van, \& Broek, P. van den (2018). Peer-feedback on Academic Writing: Undergraduate Students' Peer-feedback Role, Peer-feedback Perceptions and Essay Performance. I: Assessment \& Evaluation in Higher Education, 43 (6), 955-968.

Hvass, H., \& Heger, S. (2018). Brugbar tekstfeedback: Instruktion og træning før de studerende selv skal give og modtage. I: Dansk Universitetspoedagogisk Tidsskrift, 13 (25), under udgivelse.

Jensen, T. W. (2018). Det danske universitetsspeciale. Topografi, tekster og tendenser. Aarhus: Aarhus Universitetsforlag.

Knudsen, S. (2014). Students Are Doing It for Themselves - "the Problem-Oriented Problem" in Academic Writing for the Humanities. I: Studies in Higher Education, 39 (10), 18381859.

Kongsgaard, L.T., \& Rod, M.H. (red.) (2018). Bedre begrundet praksis. Velfœerdsudvikling efter evidensbø/gen. Frederiksberg: Samfundslitteratur.

Liu, N-F., \& Carless, D. (2006). Peer Feedback: the Learning Element of Peer Assessment. I: Teaching in Higher Education, 11, 279-290.

Malcolm, M. (2012). Examining the Implications of Learner and Supervisor Perceptions of Undergraduate Dissertation Research in Business and Management. I: Teaching in Higher Education, 17 (5), 565-576.

Monyolo, P., Khaola, P., \& Mokorotlo, G. (2014). Students' Experiences of Undergraduate Business Research and Supervision at the National University of Lesotho. I: Journal of Education and Review, 2 (10), 239-245.

Nexø Jensen, H. (2015). Opgave- og skrivevejledning I klynger. Håndbog for undervisere og vejledere på videregående uddannelser. Frederiksberg: Samfundslitteratur

Niclasen J. (2016). Klyngevejledning af specialestuderende. I: Dansk Universitetspaedagogisk Tidsskrift, 11(21), 117-86

Nicol, D., Thomson, A., \& Breslin, C. (2014). Rethinking Feedback Practices in Higher Education: A Peer Review Perspective. I: Assessment \& Evaluation in Higher Education, 39 (1), 102-122.

Nordentoft, H. M., Thomsen, R., \& Wichmann-Hansen, G. (2013). Collective academic supervision: a model for participation and learning in higher education. Higher Education, 65(5), 581-593.

Nordentoft, H.M., Hvass, H., \& Mariager-Anderson, K. (2019). Kollektiv Akademisk Vejledning. 
Fra forskning til praksis. Aarhus: Aarhus Universitetsforlag.

Overall, N.C., Deane, K.L. \& Peterson, E.R. (2011). Promoting Doctoral Students' Research SelfEfficacy: Combing Academic Guidance with Autonomy Support. I: Higher Education Research and Development, 30 (6), 791-805.

Rienecker, L., Wichmann-Hansen, G., \& Stray Jørgensen, P. (2019). God vejledning af specialer, bacheloropgaver og projekter. Frederiksberg: Samfundslitteratur.

Robert, L.D., \& Seaman, K. (2018). Good Undergraduate Dissertation Supervision: Perspectives of Supervisors and Dissertation Coordinators. I: International Journal for Academic Development, 23 (1), 28-40.

Sword, H. (2012). Stylish academic writing. Cambridge, Mass.: Harvard University Press.

Thomsen, R., \& Nordentoft, H.M. (2012). Kollektiv akademisk vejledning: et bud på en ændret organisering af vejledningen på universitetet. I: Dansk Universitetspcedagogisk Tidsskrift, 7(12), 106-116.

Todd, M., Bannister, P., and Clegg, S. (2004). Independent Inquiry and the Undergraduate Dissertation: Perceptions and Experiences of Final-Year Social Science Students. I: Assessment \& Evaluation in Higher Education, 29 (3), 335-355.

Topping, K. J. (2017). Peer Assessment: Learning by Judging and Discussing the Work of Other Learners. I: Interdisciplinary Education and Psychology, 1 (1), 1-17.

http://riverapublications.com/article/peer-assessment-learning-by-judging-anddiscussing-the-work-of-other-learners

Vereijken, M.W.C., van der Rijst, R.M., van Driel, J.H. \& Dekker, F.W. (2018). Novice Supervisors' Practices and Dilemmatic Space in Supervision of Student Research Projects. I: Teaching in Higher Education, 23 (4), 522-542.

Wichmann-Hansen, G, Thomsen, R., \& Nordentoft, H.M. (2015). Challenges in Collective Academic Supervision: supervisors' experiences from a Master Programme in Guidance and Counselling. Higher Education, 70(1), 19-33

Zhu, Q. \& Carless, D. (2018). Dialogue within Peer-feedback Processes: Clarification and Negotiation of Meaning. I: Higher Education Research \& Development, 37 (4), 883-897. 